\title{
Pulmonary Vascular Complications of Liver Disease
}

\author{
Jason S. Fritz ${ }^{1,2}$, Michael B. Fallon ${ }^{3}$, and Steven M. Kawut ${ }^{1,2,4}$ \\ ${ }^{1}$ Department of Medicine; ${ }^{2}$ Penn Cardiovascular Institute, and ${ }^{4}$ Center for Clinical Epidemiology and Biostatistics, Perelman School of \\ Medicine at the University of Pennsylvania, Philadelphia, Pennsylvania; and ${ }^{3}$ Department of Internal Medicine, The University of Texas \\ Medical School at Houston, Houston, Texas
}

\begin{abstract}
Hepatopulmonary syndrome and portopulmonary hypertension are two pulmonary vascular complications of liver disease. The pathophysiology underlying each disorder is distinct, but patients with either condition may be limited by dyspnea. A careful evaluation of concomitant symptoms, the physical examination, pulmonary function testing and arterial blood gas analysis, and echocardiographic, imaging, and hemodynamic studies is crucial to establishing (and distinguishing) these diagnoses. Our understanding of the pathobiology, natural history, and treatment of these disorders has advanced considerably over the past decade; however, the presence of either still increases the risk of morbidity and mortality in patients with underlying liver disease. There is no effective medical treatment for hepatopulmonary syndrome. Although liver transplantation can resolve hepatopulmonary syndrome, there appears to be worse survival even with transplantation. Liver transplantation poses a very high risk of death in those with significant portopulmonary hypertension, where targeted medical therapies may improve functional status and allow successful transplantation in a small number of select patients.
\end{abstract}

Keywords: hepatopulmonary syndrome; hypertension; pulmonary; liver cirrhosis; pulmonary circulation

The pulmonary circulation may be affected by pathogenic processes arising within the liver and portal venous system. Reports of abnormalities of the pulmonary vasculature found in association with coexisting chronic liver disease were first published in the 1950s $(1,2)$. Hepatopulmonary syndrome (HPS) and portopulmonary hypertension $(\mathrm{PoPH})$ are both associated with portal hypertension and/or liver disease and in simplest terms are related to excessive pulmonary microvascular dilation (in HPS) or vasoconstriction/vascular obstruction in pulmonary resistance vessels (in PoPH). The fact that these seemingly disparate conditions can occur within the same patient population (and even simultaneously or sequentially in the same patient) suggests the role of disease modifiers that determine the particular pulmonary vascular phenotype. These important pulmonary complications both commonly present with dyspnea, yet have unique pathophysiologies,

(Received in original form September 2, 2012; accepted in final form October 29, 2012) Supported by the National Institutes of Health grants K24 HL103844 and R01 HL113988 (S.M.K.).

Author Contributions: All authors contributed equally to the conception, design, and drafting of the manuscript in regard to intellectual content.

Correspondence and requests for reprints should be addressed to Steven $M$. Kawut, M.D., M.S., Perelman School of Medicine, University of Pennsylvania, 718 Blockley Hall, 423 Guardian Drive, Philadelphia, PA 19104. E-mail: kawut@upenn. edu

CME will be available for this article at http://ajrccm.atsjournals.org or at http:// cme.atsjournals.org

Am J Respir Crit Care Med Vol 187, Iss. 2, pp 133-143, Jan 15, 2013 Copyright $\odot 2013$ by the American Thoracic Society

Originally Published in Press as DOI: 10.1164/rccm.201209-1583Cl on November 15, 2012 Internet address: www.atsjournals.org diagnostic modalities, approaches to treatment, and distinct implications regarding liver transplantation (LT). A thorough understanding of the approach to evaluation and treatment of patients with cirrhosis and possible pulmonary vascular disease is imperative to minimize sequelae and to ensure appropriate management of the underlying liver disease.

\section{HEPATOPULMONARY SYNDROME}

\section{Definition}

HPS is a disorder of altered gas exchange due to abnormal capillary dilatation and/or arteriovenous fistulae within the pulmonary vascular bed (3). The European Respiratory Society Task Force on Pulmonary-Hepatic Vascular Disorders has defined HPS by the presence of (1) liver disease (usually chronic); (2) abnormal arterial oxygenation (variably defined as alveolararterial [A-a] oxygen gradient $\geqslant 15 \mathrm{~mm} \mathrm{Hg}$ [or $\geqslant 20 \mathrm{~mm} \mathrm{Hg}$ in those $\geqslant 65 \mathrm{yr}$ of age] or an arterial partial pressure of oxygen $\left[\mathrm{Pa}_{\mathrm{O}_{2}}\right]<80 \mathrm{~mm} \mathrm{Hg}$ while breathing room air) in the absence of an alternate cause; and (3) evidence of intrapulmonary vascular dilatations (IPVDs), most commonly diagnosed using contrast transthoracic echocardiography (4).

Use of the A-a gradient criterion for abnormal gas exchange captures cases of HPS that would not otherwise meet the $\mathrm{Pa}_{\mathrm{O}_{2}}$ criterion (e.g., due to cirrhosis-induced hyperventilation, lowered alveolar $\mathrm{Pa}_{\mathrm{CO}_{2}}$, and elevated alveolar oxygen tension) and leads to higher prevalence estimates of the disease (5). In a prospective study of patients referred for LT evaluation, a pulse oximetry saturation threshold of less than or equal to $97 \%$ was $64 \%$ sensitive and $68 \%$ specific for the diagnosis of HPS; a cutoff of less than or equal to $93 \%$ improved specificity to $98 \%$ at the cost of greatly reduced sensitivity (21\%) (6). Thus, pulse oximetry is not sufficiently sensitive and specific to identify patients with HPS. Therefore, arterial blood gas sampling is necessary to make this diagnosis, especially in patients with normal resting room air oxygen saturations.

\section{Pathophysiology, Histopathology, and Mechanisms}

Chronic liver disease has long been associated with abnormal systemic vasomotor tone since the original description of elevated cardiac output and reduced peripheral resistance by Kowalski and Abelmann in 1953, who posited that an imbalance between vasodilators and vasoconstrictors may be responsible (7). In 1956, two case reports described abnormal pulmonary vasculature with arteriovenous communications in patients with cirrhosis $(2,8)$. In an autopsy series of 14 patients using Micropaque pulmonary arteriography, dilated vessels were visualized along the pleural surface, particularly within the lower lobes, with a "spider nevi"-like appearance (9). One subject displayed evidence of precapillary arteriovenous communications. Microscopic analysis suggested an increase in the number of perfused intraacinar blood vessels. 
Three mechanisms account for abnormal gas exchange in HPS to varying degrees $(10,11)$. Increased alveolar capillary diameter lengthens the distance oxygen molecules must traverse to bind to red blood cell hemoglobin. This increased distance, combined with the decreased transit time commonly seen in patients with cirrhosis and elevated cardiac output $(\mathrm{CO})$, results in a diffusionperfusion limitation, such that red blood cells exit the pulmonary capillaries before full oxygen equilibration has occurred (12). Second, vascular dilatations lead to increased perfusion relative to local alveolar ventilation (V/Q mismatch) (13-15), which may be exacerbated by impaired hypoxic pulmonary vasoconstriction $(16,17)$. Supplemental oxygen therapy can at least partially ameliorate the hypoxemia resulting from these mechanisms in most patients with HPS (18). Finally, true shunt may occur when precapillary arteriovenous fistulae allow admixture of pulmonary arterial and venous blood $(19,20)$. The hypoxemia related to true shunt is refractory to supplemental oxygen.

The pathobiology of HPS has not been fully elucidated. Increased nitric oxide (NO) production with resultant vasodilation has been suggested to explain the hyperdynamic systemic circulation observed in patients with cirrhosis (21-23). In HPS, investigators have documented increased NO production in the lungs $(24,25)$, possibility mediated by endothelin receptor B signaling $(26,27)$. Additionally, animal studies suggest that gut translocation of enteric flora may alter macrophage accumulation and activation within the lung $(28,29)$ and respond to treatment with antibiotics $(29,30)$. However, a recent randomized, placebo-controlled crossover study of norfloxacin for patients with HPS did not show beneficial effects (31). Intrapulmonary macrophage activation modulates the local expression of $\mathrm{NO}$, vascular endothelial growth factor, and platelet-derived growth factor and influences the histologic as well as hemodynamic profile of HPS in rats (32).

Single nucleotide polymorphisms in genes related to angiogenesis (including endoglin, endostatin, angiopoietin-1, and TIE1) were associated with the presence of HPS in patients with portal hypertension evaluated for LT (33). Increased lung angiogenesis is also seen in the rat model of HPS, and both the angiogenesis and gas exchange abnormalities were inhibited with transfection of endostatin (34). Lung expression of the chemokine fractalkine and its receptor may lead to intrapulmonary monocyte accumulation and angiogenesis in this HPS model (35).

\section{Diagnosis and Clinical Approach}

The evaluation for HPS in a patient with liver disease depends on the documentation of the necessary criteria for diagnosis, namely IPVDs and impairment of oxygenation. Demonstration of the transpulmonary passage of a venous-injected indicator that should be trapped in normally sized lung capillaries $(\sim 8 \mu \mathrm{m})$ implies that IPVDs are present. Transthoracic contrast echocardiography (usually with agitated saline injected through a peripheral vein) remains the preferred and most commonly used modality. In principle, performing the test with the patient in an upright position may maximize the delivery of bubbles to the lower lung zones where the vascular lesions of HPS tend to predominate ( 9 , 36). The visualization of bubbles entering the left atrium three or more cardiac cycles after opacification of the right atrium is consistent with the presence of IPVDs (37). Opacification of the left atrium in less than three cardiac cycles is consistent with an intracardiac shunt. An intracardiac shunt may make it more difficult (but not impossible) to visualize late opacification. $\mathrm{Nu}$ clear scanning with radiolabeled macroaggregated albumin with assessment of abnormal accumulation within the brain is an alternative, but may be less sensitive than contrast echocardiography (38). Transesophageal contrast echocardiography may be more sensitive than transthoracic imaging $(39,40)$; however, the presence of esophageal varices limits its use in the evaluation of HPS.

Many patients with liver disease may have comorbid lung disease that can impair gas exchange and confound the clinical picture of HPS $(4,41,42)$. Thus, the finding of an abnormal A-a gradient or frank hypoxemia should prompt a methodical search for other contributing diagnoses, using chest imaging to identify parenchymal lung disease, pleural effusions, and/or atelectasis (from massive ascites) and pulmonary function testing to rule out obstructive or restrictive ventilatory defects. It is difficult to definitively diagnose HPS in patients with significant coexistent lung disease, as there is no specific test to differentiate oxygenation abnormalities due to HPS from those due to other pulmonary disorders in the presence of IPVDs. Diffusing capacity for carbon monoxide is lower in patients with cirrhosis with HPS compared with those without HPS, but it is not discriminating enough to be used diagnostically (43).

\section{Epidemiology}

The published prevalence estimates of HPS have varied according to the diagnostic criteria used. Using contemporary criteria, 8 to $33 \%$ of patients with liver disease being evaluated for LT have HPS (43-45). Although HPS typically develops in the presence of cirrhosis or portal hypertension, HPS may also occur in the setting of acute and chronic hepatitis without established portal hypertension (46-48) and in those with vascular abnormalities that limit hepatic venous outflow to the lung (Abernathy malformation, cavopulmonary shunts) $(49,50)$. Studies have not shown a reliable association between the severity of hepatic impairment and presence or severity of HPS (18, 43, 51-53); thus, patients may present with HPS at any point in the course of their liver disease. Similarly, age and sex do not appear to predispose patients with liver disease to HPS. One study has shown that HPS was more common in lifelong nonsmokers (43).

\section{Clinical Presentation}

Dyspnea is commonly reported in hepatic failure as a consequence of the disease itself, ascites with increased abdominal girth, pleural effusions, medication effects, anemia, and/or deconditioning. Forty-eight percent of LT candidates with HPS reported dyspnea, compared with $29 \%$ of LT candidates without HPS or other lung disease $(P=0.007)$ (43). Platypnea (dyspnea specifically in the upright position that is alleviated when supine) is classically described in HPS; however, orthopnea is the more common clinical complaint (43).

Patients with HPS may display cyanosis or digital clubbing $(17,54)$. Such findings are significantly more common with HPS compared with advanced liver disease alone (10 vs. $1 \%$, $P=0.007$ and 17 vs. $7 \%, P=0.03$, respectively); however, these signs are not discriminating enough to confirm or rule out the diagnosis (43). Orthodeoxia (decreased $\mathrm{Pa}_{\mathrm{O}_{2}}$ from supine to upright position) may be seen and is caused by increased shunting and V/Q mismatch in the upright position (14). Spider angiomata are found in approximately one-third of patients with or without HPS. Neurological complications, including hemorrhage, stroke, and cerebral abscess formation, have been described in HPS, presumably related to passage of embolic material from the venous to systemic arterial circulations via IPVDs $(30,45,51,55,56)$.

\section{Prognosis}

Patients with HPS have significantly worse functional class and more impaired quality of life compared with patients with 
advanced liver disease without HPS (43). Specifically, patients with HPS had lower General Health, Role Emotional, Mental Health, and Mental Component scales of the Short Form-36 Health Survey compared with patients with cirrhosis without HPS even after adjustment for age, sex, and severity of liver disease.

Patients with HPS also have a significantly lower 5-year survival rate $(0-23 \%)$ compared with that of patients with advanced liver disease without HPS (30-60\%) in the absence of LT $(51,57)$. A prospective, multicenter cohort study found that the presence of HPS in LT candidates doubled the risk of death compared with those without HPS, even after adjustment for potential confounders (43) (Figure 1). Patients with HPS awaiting LT experience an average decline of approximately $5 \mathrm{~mm} \mathrm{Hg} / \mathrm{yr}$ in $\mathrm{Pa}_{\mathrm{O}_{2}}$ (51). Some studies have suggested that more severe hypoxemia in HPS confers a worse prognosis with or without LT $(51,57-60)$; however, this finding has not been replicated in all series $(43,61)$. Patients with HPS frequently die of hepatic failure, gastrointestinal hemorrhage, sepsis/infection, and hepatorenal syndrome, all complications of liver disease $(51,57,58)$, suggesting that HPS reflects a systemic disorder with implications that extend beyond pulmonary or hypoxemia-related events.

\section{Treatment}

There is no accepted medical therapy for HPS. Vaccination for influenza and pneumococcus is indicated for patients with advanced liver disease (62). The use of supplemental oxygen to correct hypoxemia at rest, with exercise, or during sleep seems intuitive; however, no data are available to confirm clinical benefit. Various interventions targeting purported pathways related to NO signaling or pulmonary or splanchnic vasoregulation have been largely unsuccessful in HPS. By virtue of its ability to block tumor necrosis factor- $\alpha$ and macrophage-derived NO synthesis, pentoxifylline has garnered attention, as rodent studies suggested potential benefit in experimental HPS $(63,64)$. However, two small studies in patients with HPS reached conflicting conclusions $(65,66)$. Occasionally, patients may present with large pulmonary arteriovenous malformations that are amenable to angiographic embolization, which can at least transiently improve oxygenation (67); however, this is the rare exception. Transjugular intrahepatic portosystemic shunt (TIPS) placement is not recommended for the treatment of HPS in recent guidelines

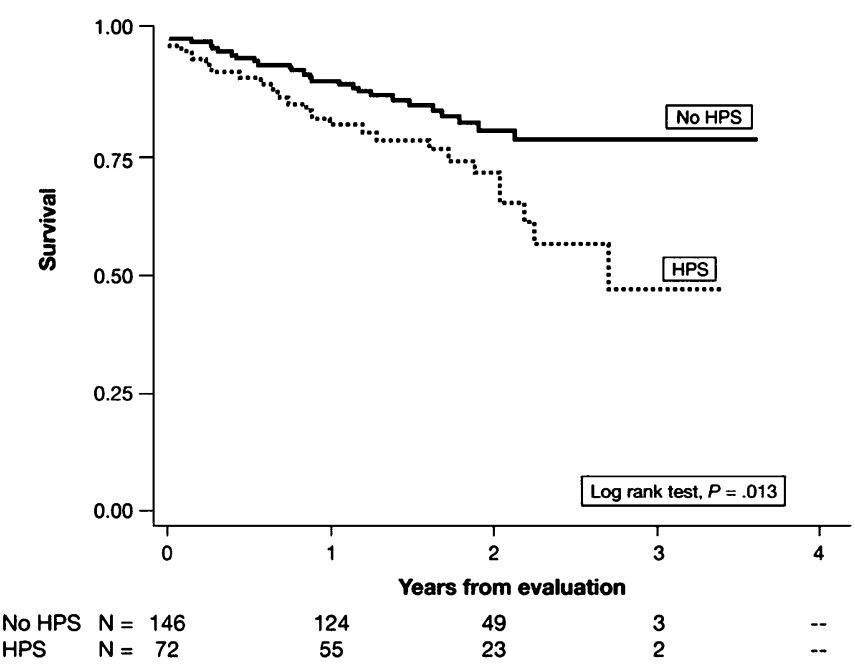

Figure 1. Kaplan-Meier survival estimates of lung transplant candidates with and without hepatopulmonary syndrome (HPS). Reprinted by permission from Reference 43. from the American Association for the Study of Liver Disease $(68,69)$.

LT remains the only known treatment for HPS. Several studies suggest that LT is associated with improved survival in HPS $(51,53)$. Swanson and colleagues showed that patients with HPS who underwent LT (with mean $\mathrm{Pa}_{\mathrm{O}_{2}} 57 \pm 17 \mathrm{~mm} \mathrm{Hg}$ ) had better 5-year survival compared with those who did not $(\sim 75$ vs. $23 \%$, respectively) (51). This same group recently published longer-term follow-up in an expanded cohort of patients, which appears to confirm a survival benefit of LT in HPS, although this did not reach statistical significance (hazard ratio for death in LT group versus non-LT group $=0.52$; 95\% CI, 0.26-1.05; $P=0.067)$ (61). As a nonrandomized study without multivariate analysis, it is possible that confounding factors could play a role. A series of 21 patients with HPS transplanted after $2004(\sim 50 \%$ with $\mathrm{Pa}_{\mathrm{O}_{2}}<50 \mathrm{~mm} \mathrm{Hg}$ ) showed an overall survival rate of $95 \%$, with a median follow-up of 20.2 months (range, 1.8-70.1) (53). Advances in general transplant care or patient selection may have contributed to the higher survival seen in this cohort.

Improvement in or resolution of abnormalities in gas exchange after LT occurs in the majority of individuals with HPS who survive LT $(42,51,53,58,59,70)$. Although hypoxemia may persist or worsen transiently after LT $(42,53)$, most will demonstrate normal gas exchange within 6 to 12 months post-transplant $(51,53,58,70)$, although delayed resolution beyond 12 months has been reported (42). More severe preoperative derangements in gas exchange $\left(\mathrm{Pa}_{\mathrm{O}_{2}}<52 \mathrm{~mm} \mathrm{Hg}\right.$ or A-a gradient $>65 \mathrm{~mm} \mathrm{Hg}$ ) or shunt fraction have been associated with a prolonged time to resolution after LT $(42,53)$.

Even though hypoxemia usually resolves after LT, HPS may increase the risk of post-transplant death. In a prospective cohort of 218 patients evaluated for LT (43), HPS was associated with a doubling of the risk of death after consideration of the severity of liver disease and performance and timing of LT. This suggests that even if LT is performed, HPS still has an adverse impact on outcomes. In a prospective study, a combination of preoperative room air $\mathrm{Pa}_{\mathrm{O}_{2}}$ less than $50 \mathrm{~mm} \mathrm{Hg}$ and shunt fraction (from quantitative perfusion scan) greater than or equal to $20 \%$ conferred a $75 \%$ risk of death within 10 weeks after LT (58).

Although HPS was once considered a contraindication to LT, it is now considered an indication, given the acceptable outcomes and the usual resolution of HPS post-transplant. Patients with HPS and $\mathrm{Pa}_{\mathrm{O}_{2}}$ less than $60 \mathrm{~mm} \mathrm{Hg}$ receive additional Model for End-Stage Liver Disease (MELD) points and increased priority for LT (Organ Procurement and Transplantation Network policy 3.6.4.5.1 [71, 72]). Continued assessment of the impact of this policy on outcomes and organ use may be warranted so as to optimize equitable organ allocation (73).

\section{PORTOPULMONARY HYPERTENSION}

\section{Definition}

PoPH is pulmonary arterial hypertension $(\mathrm{PAH})$ associated with portal hypertension (74). PAH (or Group 1 of the Dana Point classification of pulmonary hypertension) includes other forms of precapillary pulmonary arteriopathy, such as idiopathic (formerly "primary") and heritable PAH as well as forms associated with drug/toxin use, congenital heart disease, connective tissue disease, chronic hemolytic anemias, and schistosomiasis or HIV infection.

\section{Pathophysiology, Histopathology, and Mechanisms}

Pathologic changes common to all forms of PAH include muscularization of small pulmonary arteries, intimal thickening, smooth 
muscle hypertrophy, in situ thrombosis, and plexiform lesions (75). There is no histopathologic profile that distinguishes $\mathrm{PoPH}$ from other forms of PAH.

It is unclear whether the mechanisms of other types of PAH cause PoPH. Expression of prostacyclin synthase appears reduced within pulmonary arteries of patients with $\mathrm{PAH}$ as well as PoPH (76). Alterations in endothelin biology have been identified in idiopathic PAH (IPAH) as well as cirrhosis and portal hypertension (77). Patients with refractory ascites and $\mathrm{PoPH}$ have higher levels of pulmonary arterial endothelin-1 levels compared with patients without PoPH (78). Genetic variants of aromatase and estrogen receptor $\alpha$ were associated with the risk of $\mathrm{PoPH}$, and the "high-risk" aromatase genotype increased plasma estradiol levels (79). Single nucleotide polymorphisms in the genes encoding phosphodiesterase-5 (PDE5) and NADPH oxidase 4 were also associated with an increased risk of PoPH. Estrogen signaling, cGMP metabolism, and oxidative stress have important roles in other forms of PAH (80-86).

\section{Diagnosis and Clinical Approach}

A clinical diagnosis of PoPH can be established in the setting of compatible hemodynamics in a patient with portal hypertension in the absence of coexisting conditions that could cause pulmonary hypertension. It should be emphasized that the development of $\mathrm{PoPH}$ requires the presence of portal hypertension (of either intra- or extrahepatic origin) and not simply chronic liver disease or cirrhosis per se. Current guidelines require a resting mean pulmonary artery pressure (mPAP) greater than $25 \mathrm{~mm} \mathrm{Hg}$ with a pulmonary capillary wedge pressure less than or equal to $15 \mathrm{~mm} \mathrm{Hg}$ and pulmonary vascular resistance (PVR) greater than $240 \mathrm{dyn} \cdot \mathrm{s} / \mathrm{cm}^{5}$ from right heart catheterization (RHC) $(87,88)$. The hemodynamic criteria are key to establishing this diagnosis, which ultimately is a clinical one. Portal hypertension is itself associated with a hyperdynamic circulatory state, sodium avidity, and volume overload, which can cause pulmonary hypertension with a normal transpulmonary gradient (TPG) and PVR, which is not $\mathrm{PoPH}$ and does not appear to carry the same dire implications regarding outcome.

Two-dimensional Doppler echocardiography plays an important role in the evaluation of symptomatic patients with cirrhosis with suspected PoPH and in the screening of candidates for LT. In a prospective study of LT candidates, a cutoff for pulmonary artery systolic pressure (PASP) greater than $30 \mathrm{~mm} \mathrm{Hg}$ had a negative predictive value of $100 \%$, but the positive predictive value was only $59 \%$. This means that no patient with PoPH had a PASP below the cutoff, but $40 \%$ of individuals above the cutoff did not actually have PoPH (89). The high negative predictive value of two-dimensional Doppler echocardiography justifies its use as a screening modality as recommended by the American Association for the Study of Liver Disease and the American Heart Association (Class IIa; Level of Evidence B) for all patients being considered for LT $(90,91)$. Although there is no consensus surrounding the indications for further evaluation, LT candidates with a PASP greater than $50 \mathrm{~mm} \mathrm{Hg}$ and/or with significant right ventricular hypertrophy or dysfunction likely require RHC to either confirm hemodynamics consistent with $\mathrm{PoPH}$ or (as importantly) rule out PoPH and avoid inappropriate management based on an erroneous diagnosis.

\section{Epidemiology}

As with HPS, the prevalence estimates of PoPH are influenced by the specific criteria used to define the disease as well as the population studied. An autopsy study of more than 17,000 subjects identified changes suggestive of a pulmonary arteriopathy in $0.13 \%$ and in $0.73 \%$ of those with cirrhosis (92). A prospective study of 1,235 patients evaluated for liver transplantation (all with Child-Turcotte-Pugh score $\geqslant 7$ ) showed that $5 \%$ met current hemodynamic criteria for PoPH (93). Previous retrospective analyses have generally yielded similar estimates $(89,94$ 96). Neither the severity of liver disease $(89,97-100)$ nor the degree of portal hypertension (as measured by the hepatic venous pressure gradient) $(89,97)$ predict the presence or severity of PoPH.

In a multicenter case-control study, female sex and a diagnosis of autoimmune hepatitis were independent risk factors for PoPH in patients evaluated for LT (100). Those with hepatitis C infection were less likely to have PoPH. The sex predilection mirrors that observed for idiopathic PAH. A recent casecontrol study identified a higher prevalence of large spontaneous portosystemic shunts and hepatofugal portal blood flow among patients with moderate to severe $\mathrm{PoPH}$ compared with milder or no PoPH (101).

PoPH accounts for approximately 5 to $10 \%$ of patients with PAH in the United States and France (102-104). A contemporary U.S.-based PAH registry has suggested that, despite similar functional class, patients with PoPH display less severely impaired hemodynamics (lower mPAP and PVR, higher CO) at presentation compared with patients with IPAH (105).

\section{Clinical Presentation}

Dyspnea is a common feature of PoPH but is nonspecific. Findings on physical examination include elevated jugular venous pressure, a prominent $\mathrm{P}_{2}$, a holosystolic murmur indicative of tricuspid regurgitation, a right ventricular heave, and edema. However, the common presence of volume overload and pulmonary hypertension of other types in advanced liver disease makes it difficult to use the physical examination to alter the clinical suspicion of PoPH. ECG often shows right axis deviation, right ventricular hypertrophy, or right bundle branch block. A majority of patients with PoPH will demonstrate enlarged pulmonary arteries or cardiomegaly on chest radiography $(100,106)$.

Elevations in A-a gradient may be seen in up to $80 \%$ of patients with PoPH $(107,108)$. IPAH is associated with a mild reduction in arterial oxygen tension $(109,110)$, believed to be related to $\mathrm{V} / \mathrm{Q}$ mismatch and reduced mixed venous oxygen saturation $(111,112)$. In the context of liver disease, however, moderate to severe hypoxemia $\left(\mathrm{Pa}_{\mathrm{O}_{2}} \leqslant 70 \mathrm{~mm} \mathrm{Hg}\right)$ is more consistent with HPS, as only $15 \%$ of patients with $\mathrm{PoPH}$ in one small series exhibited a $\mathrm{Pa}_{\mathrm{O}_{2}}$ below this threshold (108). $\mathrm{PoPH}$ with a patent foramen ovale (or atrial septal defect) with intracardiac right-to-left shunting is an exception (113).

\section{Prognosis and Implications for Liver Transplant}

PoPH is associated with reduced survival. Available reports suggest a 1 -year survival of approximately 35 to $46 \%$ without treatment $(106,114,115)$. A retrospective study (115) as well as a large, multicenter prospective U.S. registry (105) in the modern treatment era both suggested higher mortality for patients with $\mathrm{PoPH}$ relative to patients with IPAH despite higher $\mathrm{CO}$ and lower PVR in PoPH (Figures 2 and 3). A retrospective cohort study of patients with $\mathrm{PoPH}$ from France reported an increased risk of death with more severe cirrhosis and lower cardiac index (116) (Figure 4). Patients often die of right ventricular failure or from complications from hepatic disease, although the relative frequencies with which each occurs vary by study and potentially by therapy $(99,105,106,114,116)$. 


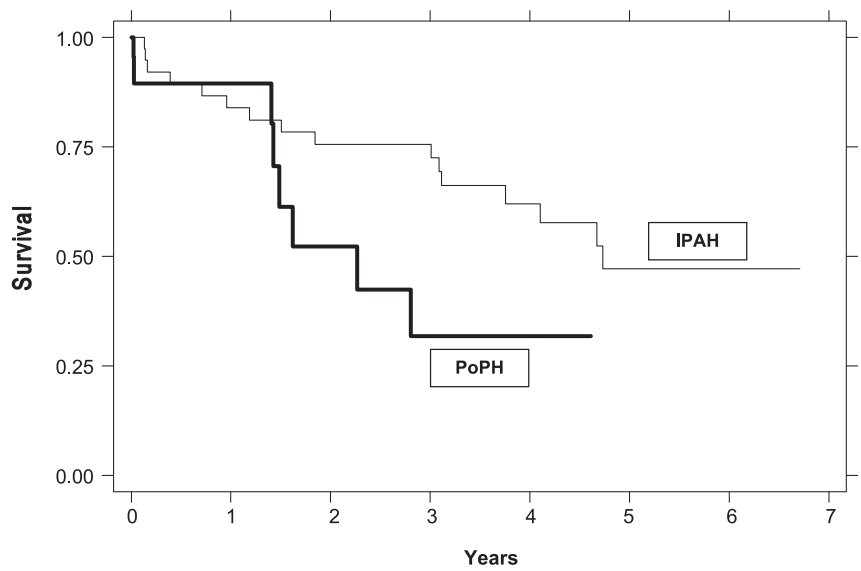

Figure 2. Survival functions for portopulmonary hypertension (PoPH) versus idiopathic pulmonary arterial hypertension (IPAH), adjusted for age and race/ethnicity. Reprinted by permission from Reference 115.

The risk of perioperative mortality after LT is increased in patients with PoPH $(60,114,117)$. LT is associated with acute hemodynamic changes with contributions from mechanical ventilation, anesthesia, volume shifts, and replacement of a diseased and restricted hepatic portal circulation with a postischemic graft. Abrupt intraoperative swings in cardiac filling pressures and production of vasoactive substances may precipitate right ventricular failure in susceptible patients with PoPH $(60,114$, 118). In one of the earliest studies in untreated patients with PoPH diagnosed at the time of transplantation, all patients with mPAP greater than $50 \mathrm{~mm} \mathrm{Hg}$ died, whereas all patients with mPAP less than $35 \mathrm{~mm} \mathrm{Hg}$ and TPG less than $15 \mathrm{~mm} \mathrm{Hg}$ survived (117). Patients with mPAP between 35 and50 mm Hg or PVR greater than $250 \mathrm{dyn} \cdot \mathrm{s} / \mathrm{cm}^{5}$ demonstrated a $50 \%$ mortality rate. In a prospective, multicenter study of patients with PoPH undergoing LT (mean mPAP $\sim 45 \mathrm{~mm} \mathrm{Hg}$ ), a 36\% mortality rate was observed, with all deaths occurring within 18 days of LT and right heart failure accounting for a large fraction. More than one-third of the deaths occurred intraoperatively (60).

With the advent of routine screening for PoPH in LT candidates, clinicians have used PAH-specific therapy in an attempt to mitigate the morbidity and mortality associated with LT (see section on Treatment below). However, even with treatment, only a very small number of patients are deemed eligible for transplantation and, even then, with a continued high risk of mortality. In a series from the University of California, San Francisco, 36 PoPH cases were identified over a 7-year period.
Nineteen of these were treated with intravenous epoprostenol, but only five improved sufficiently to be deemed candidates for LT, of whom only two $(\sim 6 \%)$ underwent LT; both patients had persistent PoPH post-transplant (98). At the Mayo Clinic over 13 years, only 9 out of 74 PoPH cases (12\%) received LT, of whom three died, all within 1 month of LT (114). Sussman and colleagues reported on eight PoPH cases, four of whom underwent successful LT (119).

There have been reports of the resolution of PoPH after LT, although available data suggest this is the exception rather than the rule in the setting of significant PoPH $(98,114,116,117,120)$. Predictors of hemodynamic improvement after LT have not been identified. Recurrence of PoPH after a period of resolution occurring in conjunction with failure of the hepatic allograft has been described (121). PoPH may develop after LT in patients with preexisting HPS (122). It is not known whether this represents an "unmasking" of concomitant PoPH or the development of de novo obliterative pulmonary vascular disease.

Despite the unpredictability in outcomes after LT, a MELD exception is available for PoPH (Organ Procurement and Transplantation Network policy 3.6.4.5.6 [71, 123]). To qualify, LT candidates with $\mathrm{PoPH}$ must demonstrate a positive hemodynamic response to therapy, defined as an mPAP less than $35 \mathrm{~mm} \mathrm{Hg}$ and PVR to less than $400 \mathrm{dyn} \cdot \mathrm{s} / \mathrm{cm}^{5}$.

When otherwise indicated for the treatment of variceal bleeding or refractory ascites, TIPS placement should be considered cautiously in the patient with pulmonary hypertension. The typical post-procedure hemodynamic changes of increased right ventricular filling pressures and increased cardiac output may be poorly tolerated in the patient with significant elevations in PVR and right ventricular volume or pressure overload (124, $125)$. Recent guidelines have proposed that severe pulmonary hypertension (defined as mPAP $>45 \mathrm{~mm} \mathrm{Hg}$ ) and severe tricuspid regurgitation are absolute contraindications to TIPS, whereas moderate pulmonary hypertension is a relative contraindication (69). The ability to tolerate TIPS in the setting of pulmonary hypertension is likely based on the type (PoPH vs. high-output or volume expanded states), cardiac filling pressures, and right ventricular function.

\section{Treatment}

The histopathologic and clinical similarities between PoPH and other forms of PAH have provided a rationale for the use of $\mathrm{PAH}$ therapies in $\mathrm{PoPH}$, although this patient subset has been excluded from virtually all clinical trials of these therapies. The role of "conventional" therapies (anticoagulation and calcium channel blockers [CCB]) in PoPH remains undefined. Patients with $\mathrm{PoPH}$ were excluded from the observational studies that suggested a long-term survival benefit with oral

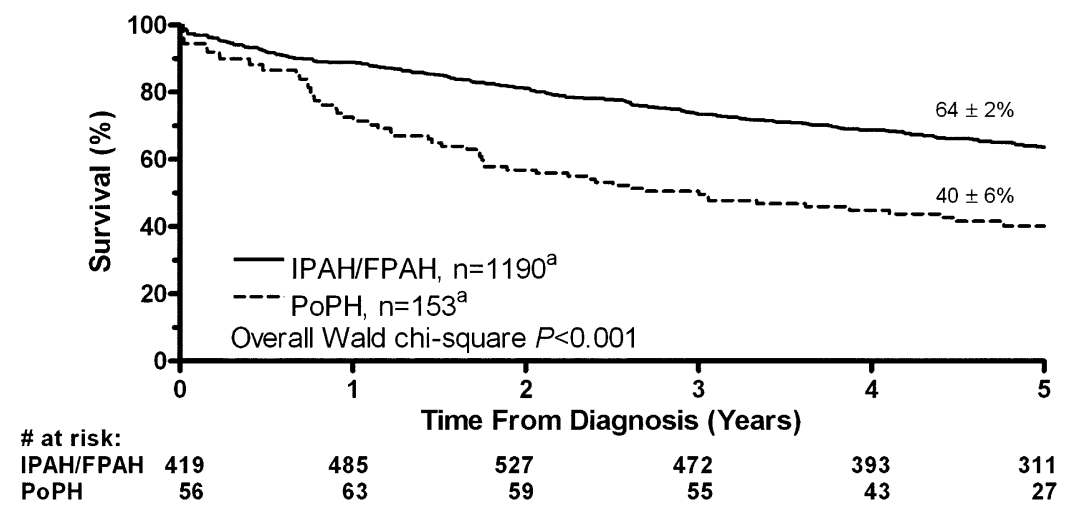

Figure 3. Kaplan-Meier survival estimates for portopulmonary hypertension (PoPH) versus idiopathic pulmonary arterial hypertension (IPAH) or familial pulmonary arterial hypertension (FPAH). Reprinted by permission from Reference 105 . 


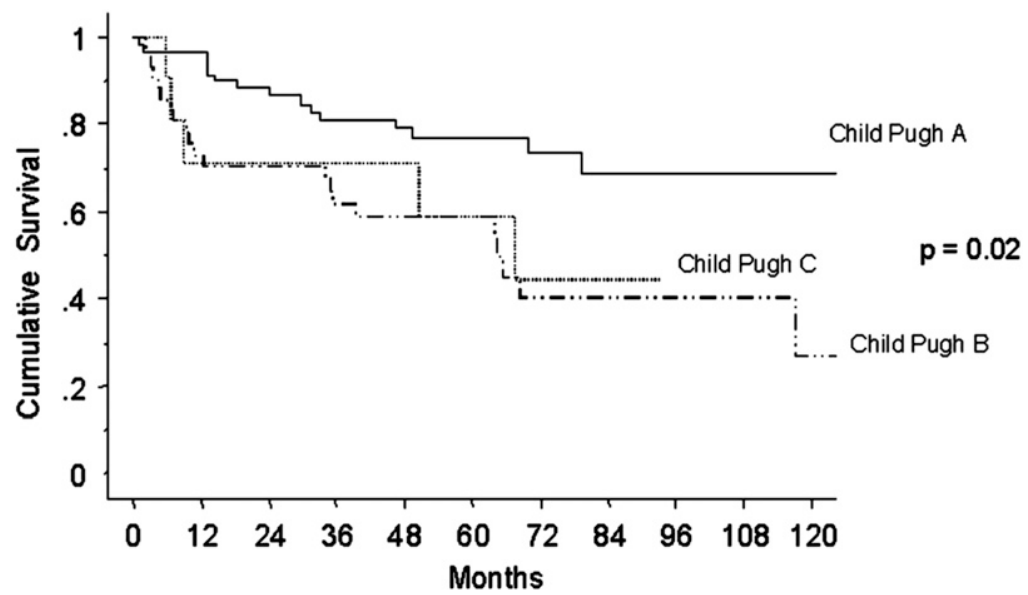

Figure 4. Kaplan-Meier survival estimates of patients with portopulmonary hypertension stratified by grade of cirrhosis. Reprinted by permission from Reference 116.

\begin{tabular}{|c|c|c|c|c|c|c|c|c|c|c|c|c|}
\hline \multirow{2}{*}{$\begin{array}{l}\text { Subjects } \\
\text { at risk }\end{array}$} & 61 & 57 & 51 & 43 & 39 & 31 & 19 & 12 & 7 & 5 & 3 & Child Pugh A \\
\hline & 45 & 28 & 26 & 21 & 19 & 14 & 8 & 5 & 4 & 3 & 1 & Child $P_{4}$ \\
\hline $\begin{array}{c}\text { Subjects } \\
\text { at risk }\end{array}$ & 13 & 7 & 7 & 7 & 7 & 5 & 2 & 1 & 0 & U & 0 & \\
\hline
\end{tabular}

anticoagulation (126-129), and cirrhosis-related bleeding diatheses and varices likely present strong contraindications to anticoagulation in most patients with PoPH.

Current guidelines recommend using CCB therapy chronically only in those patients with $\mathrm{PAH}$ who demonstrate acute vasoreactivity to vasodilator and $\mathrm{CCB}$ challenge during $\mathrm{RHC}$ $(87,130)$. A recent study from Clamart, France showed that only 2 of 153 patients with PoPH (1.3\%) demonstrated an acute vasodilator response (using older criteria), of whom only one exhibited a favorable long-term response with CCB therapy (131). Acute vasodilator testing therefore appears unlikely to be helpful or necessary in patients with $\mathrm{PoPH}$; however, there is lack of consensus $(87,132)$.

Patients with cirrhosis and esophageal varices are often treated with $\beta$-blockers. In patients with more advanced PoPH (mean PAP $>35-40 \mathrm{~mm} \mathrm{Hg}$ ), withdrawal of $\beta$-blocker therapy may increase cardiac output (via release of chronotropic response) as well as exercise capacity (133). Therefore, the risk:benefit ratio of $\beta$-blocker therapy should be considered along with alternative means of controlling variceal bleeding risk (e.g., band ligation) in patients with $\mathrm{PoPH}$. As with other forms of $\mathrm{PAH}$, oxygen supplementation to correct hypoxemia and diuretics to maintain euvolemia are commonly used.

\section{Prostacyclin Analogs}

Prostacyclin analogs possess vasodilatory, antithrombotic, and antiproliferative properties and are effective in other forms of PAH. Numerous case reports/series have reported improvements in hemodynamics with the use of intravenous epoprostenol in PoPH (98, 119, 120, 134-136); however, definitive improvements in survival have not been found $(116,119)$. Progressive splenomegaly and thrombocytopenia have been documented (137, 138); slower titration and target doses lower than those used in other forms of PAH may prevent the former issue. Favorable hemodynamic effects have been reported with intravenous treprostinil (139) and inhaled iloprost as well $(99,140)$.

\section{PDE5 Inhibitors}

PDE5 inhibitors prevent the metabolism of cGMP, which mediates the vascular effects of NO. Sildenafil is an oral PDE5 inhibitor approved for treatment of PAH (141). Small retrospective series suggest that sildenafil improves functional capacity and decreases PVR and mPAP in PoPH (142-144), in some cases allowing LT $(143,144)$. The dosing in these studies was variable and included regimens beyond the currently U.S. Food and Drug Administration (FDA)-approved dose of $20 \mathrm{mg}$ three times daily.

\section{Endothelin Receptor Antagonists}

The endothelin pathway in cirrhosis and portal and pulmonary hypertension presents a potential therapeutic target for PoPH. Bosentan is an orally available dual endothelin receptor antagonist approved for use in PAH (145); the FDA label recommends avoiding bosentan in patients with moderate to severe liver dysfunction or elevated transaminases. Several observational studies have shown that bosentan leads to improvements in exercise capacity and hemodynamics in $\mathrm{PoPH}$ associated with Child-Pugh class A-B (146-150) as well as Child-Pugh class $\mathrm{C}$ cirrhosis (151). Hoeper and colleagues reported a 3-year survival rate of $89 \%$ in a retrospective study of 18 patients with PoPH treated with bosentan (99). One patient exhibited a rise in liver transaminases greater than three times the upper limit of normal, which resolved with dose reduction. A recent retrospective study included 34 patients with $\mathrm{PoPH}$ treated with bosentan (6 with portal vein thrombosis, 19 with Child-Pugh class A cirrhosis, and 9 with Child-Pugh class B cirrhosis) (152). After 5 months, there was a $31 \%$ reduction in PVR and $39 \%$ increase in cardiac index. Seven patients $(5.5 \%)$ developed elevations in liver transaminases greater than three times the upper limit of normal, which resolved with dose reduction or discontinuation. Ambrisentan is a selective endothelin-A receptor antagonist approved for treatment of PAH (153). The FDA label does not recommend ambrisentan in patients with moderate to severe hepatic impairment. Cartin-Ceba and colleagues reported a cohort of 13 patients with PoPH (62\% Child-Pugh class A) treated with ambrisentan (median exposure 390 d) (154). Patients demonstrated improved functional class, increased cardiac output, and a mean reduction in PVR of $61 \%$. No significant changes in liver function parameters were observed.

\section{CONCLUSIONS}

There is better understanding of the epidemiology, natural history, and management of patients with HPS and PoPH. With 
appropriate identification of these disorders, we can more accurately determine the risk of untoward outcomes both within and outside the context of LT. The identification of HPS with significant hypoxemia can prioritize a patient for LT, which can normalize gas exchange. Among etiologies of $\mathrm{PAH}$, the prognosis of $\mathrm{PoPH}$ is particularly poor despite a more favorable hemodynamic profile. Screening of all LT candidates with echocardiography is recommended to identify patients who require RHC to diagnose $\mathrm{PoPH}$ and stratify risk. For the patient with $\mathrm{PoPH}$ in need of LT due to advanced liver disease, treatment with $\mathrm{PAH}$ therapies should be considered in an attempt to reduce mPAP, PVR, and TPG and increase cardiac output. Most experience has come from intravenous epoprostenol, but currently available oral agents may be of benefit in patients with milder disease or in those who are not candidates for parenteral therapy. LT in the patient with significant PoPH remains a high-risk proposition, but may be appropriate in carefully selected candidates.

The identification of predisposing genetic abnormalities in some afflicted patients has the potential to better identify at-risk groups as well as provide opportunities for therapeutic interventions. In HPS, future therapies aimed at decreasing intrapulmonary shunting and improving gas exchange abnormalities might be expected to improve outcomes. Patients with PoPH have been excluded from therapeutic trials in PAH. Inclusion of subjects with $\mathrm{PoPH}$ in future studies and research focused on outcomes pre- and post-LT may help to inform treatment decisions and further define the role of medical therapy and LT. With both disorders, close collaboration between cardiologists, pulmonologists, hepatologists, and surgical transplant teams is necessary to not only optimize outcomes but also promote multidisciplinary research efforts to identify effective therapeutic approaches.

Author disclosures are available with the text of this article at www.atsjournals.org

\section{References}

1. Mantz FA Jr, Craige E. Portal axis thrombosis with spontaneous portacaval shunt and resultant cor pulmonale. AMA Arch Pathol 1951; 52:91-97.

2. Hoffbauer FW, Rydell R. Multiple pulmonary arteriovenous fistulas in juvenile cirrhosis. Am J Med 1956;21:450-460.

3. Krowka MJ. Hepatopulmonary syndrome versus portopulmonary hypertension: distinctions and dilemmas. Hepatology 1997;25: 1282-1284.

4. Rodriguez-Roisin R, Krowka MJ, Hervé P, Fallon MB. Pulmonaryhepatic vascular disorders (PHD): on behalf of the ERS Task Force on Pulmonary-Hepatic Vascular Disorders (PHD) Scientific Committee. Eur Respir J 2004;24:861-880.

5. Rodriguez-Roisin R, Krowka MJ. Hepatopulmonary syndromea liver-induced lung vascular disorder. N Engl J Med 2008;358: 2378-2387.

6. Arguedas MR, Singh H, Faulk DK, Fallon MB. Utility of pulse oximetry screening for hepatopulmonary syndrome. Clin Gastroenterol Hepatol 2007;5:749-754.

7. Kowalski HJ, Abelmann WH. The cardiac output at rest in Laennec's cirrhosis. J Clin Invest 1953;32:1025-1033.

8. Hales MR. Multiple small arteriovenous fistulae of the lungs. Am J Pathol 1956;32:927-943.

9. Berthelot P, Walker JG, Sherlock S, Reid L. Arterial changes in the lungs in cirrhosis of the liver-lung spider nevi. N Engl J Med 1966; 274:291-298.

10. Rodriguez-Roisin R, Agusti AG, Roca J. The hepatopulmonary syndrome: new name, old complexities. Thorax 1992;47:897-902.

11. Schraufnagel DE, Kay JM. Structural and pathologic changes in the lung vasculature in chronic liver disease. Clin Chest Med 1996;17: $1-15$.

12. Genovesi MG, Tierney DF, Taplin GV, Eisenberg H. An intravenous radionuclide method to evaluate hypoxemia caused by abnormal alveolar vessels: limitation of conventional techniques. Am Rev Respir Dis 1976;114:59-65.
13. Martínez GP, Barberà JA, Visa J, Rimola A, Paré JC, Roca J, Navasa M, Rodés J, Rodriguez-Roisin R. Hepatopulmonary syndrome in candidates for liver transplantation. J Hepatol 2001;34:651-657.

14. Gómez FP, Martínez-Palli G, Barberà JA, Roca J, Navasa M, Rodriguez-Roisin R. Gas exchange mechanism of orthodeoxia in hepatopulmonary syndrome. Hepatology 2004;40:660-666.

15. Hedenstierna G, Soderman C, Eriksson LS, Wahren J. Ventilationperfusion inequality in patients with non-alcoholic liver cirrhosis. Eur Respir J 1991;4:711-717.

16. Daoud FS, Reeves JT, Schaefer JW. Failure of hypoxic pulmonary vasoconstriction in patients with liver cirrhosis. J Clin Invest 1972;51: 1076-1080.

17. Rodriguez-Roisin R, Roca J, Agusti AG, Mastai R, Wagner PD, Bosch J. Gas exchange and pulmonary vascular reactivity in patients with liver cirrhosis. Am Rev Respir Dis 1987;135:1085-1092.

18. Krowka MJ, Wiseman GA, Burnett OL, Spivey JR, Therneau T, Porayko MK, Wiesner RH. Hepatopulmonary syndrome: a prospective study of relationships between severity of liver disease, $\mathrm{PaO}(2)$ response to $100 \%$ oxygen, and brain uptake after $(99 \mathrm{~m}) \mathrm{Tc}$ MAA lung scanning. Chest 2000;118:615-624.

19. Castaing $Y$, Manier G. Hemodynamic disturbances and $V_{A} / Q$ matching in hypoxemic cirrhotic patients. Chest 1989;96:1064-1069.

20. Edell ES, Cortese DA, Krowka MJ, Rehder K. Severe hypoxemia and liver disease. Am Rev Respir Dis 1989;140:1631-1635.

21. Vallance P, Moncada S. Hyperdynamic circulation in cirrhosis: a role for nitric oxide? Lancet 1991;337:776-778.

22. Guarner C, Soriano G, Tomas A, Bulbena O, Novella MT, Balanzo J, Vilardell F, Mourelle M, Moncada S. Increased serum nitrite and nitrate levels in patients with cirrhosis: relationship to endotoxemia. Hepatology 1993;18:1139-1143.

23. La Villa G, Barletta G, Pantaleo P, Del Bene R, Vizzutti F, Vecchiarino S, Masini E, Perfetto F, Tarquini R, Gentilini P, et al. Hemodynamic, renal, and endocrine effects of acute inhibition of nitric oxide synthase in compensated cirrhosis. Hepatology 2001;34:19-27.

24. Cremona G, Higenbottam TW, Mayoral V, Alexander G, Demoncheaux E, Borland C, Roe P, Jones GJ. Elevated exhaled nitric oxide in patients with hepatopulmonary syndrome. Eur Respir J 1995;8: 1883-1885.

25. Fallon MB, Abrams GA, Luo B, Hou Z, Dai J, Ku DD. The role of endothelial nitric oxide synthase in the pathogenesis of a rat model of hepatopulmonary syndrome. Gastroenterology 1997;113:606-614.

26. Luo B, Liu L, Tang L, Zhang J, Stockard CR, Grizzle WE, Fallon MB. Increased pulmonary vascular endothelin $\mathrm{B}$ receptor expression and responsiveness to endothelin-1 in cirrhotic and portal hypertensive rats: a potential mechanism in experimental hepatopulmonary syndrome. J Hepatol 2003;38:556-563.

27. Zhang J, Ling Y, Tang L, Luo B, Pollock DM, Fallon MB. Attenuation of experimental hepatopulmonary syndrome in endothelin B receptor-deficient rats. Am J Physiol Gastrointest Liver Physiol 2009; 296:G704-G708.

28. Garcia-Tsao G, Lee FY, Barden GE, Cartun R, West AB. Bacterial translocation to mesenteric lymph nodes is increased in cirrhotic rats with ascites. Gastroenterology 1995;108:1835-1841.

29. Rabiller A, Nunes H, Lebrec D, Tazi KA, Wartski M, Dulmet E, Libert JM, Mougeot C, Moreau R, Mazmanian M, et al. Prevention of gram-negative translocation reduces the severity of hepatopulmonary syndrome. Am J Respir Crit Care Med 2002;166:514-517.

30. Anel RM, Sheagren JN. Novel presentation and approach to management of hepatopulmonary syndrome with use of antimicrobial agents. Clin Infect Dis 2001;32:E131-E136.

31. Gupta S, Faughnan ME, Lilly L, Hutchison S, Fowler R, Bayoumi AM. Norfloxacin therapy for hepatopulmonary syndrome: a pilot randomized controlled trial. Clin Gastroenterol Hepatol 2010;8:1095-1098.

32. Thenappan T, Goel A, Marsboom G, Fang YH, Toth PT, Zhang HJ, Kajimoto H, Hong Z, Paul J, Wietholt C, et al. A central role for CD68(+) macrophages in hepatopulmonary syndrome: reversal by macrophage depletion. Am J Respir Crit Care Med 2011;183: 1080-1091.

33. Roberts KE, Kawut SM, Krowka MJ, Brown RS Jr, Trotter JF, Shah V, Peter I, Tighiouart H, Mitra N, Handorf E, et al. Genetic risk factors for hepatopulmonary syndrome in patients with advanced liver disease. Gastroenterology 2010;139:130-139. 
34. Zhang J, Luo B, Tang L, Wang Y, Stockard CR, Kadish I, Van Groen T, Grizzle WE, Ponnazhagan S, Fallon MB. Pulmonary angiogenesis in a rat model of hepatopulmonary syndrome. Gastroenterology 2009;136:1070-1080.

35. Zhang J, Yang W, Luo B, Hu B, Maheshwari A, Fallon MB. The role of $\mathrm{CX}(3) \mathrm{CL} 1 / \mathrm{CX}(3) \mathrm{CR} 1$ in pulmonary angiogenesis and intravascular monocyte accumulation in rat experimental hepatopulmonary syndrome. J Hepatol 2012;57:752-758.

36. McAdams HP, Erasmus J, Crockett R, Mitchell J, Godwin JD McDermott VG. The hepatopulmonary syndrome: radiologic findings in 10 patients. AJR Am J Roentgenol 1996;166:1379-1385.

37. Shub C, Tajik AJ, Seward JB, Dines DE. Detecting intrapulmonary right-to-left shunt with contrast echocardiography: observations in a patient with diffuse pulmonary arteriovenous fistulas. Mayo Clin Proc 1976;51:81-84.

38. Abrams GA, Jaffe CC, Hoffer PB, Binder HJ, Fallon MB. Diagnostic utility of contrast echocardiography and lung perfusion scan in patients with hepatopulmonary syndrome. Gastroenterology 1995;109: 1283-1288.

39. Vedrinne JM, Duperret S, Bizollon T, Magnin C, Motin J, Trepo C, Ducerf C. Comparison of transesophageal and transthoracic contrast echocardiography for detection of an intrapulmonary shunt in liver disease. Chest 1997;111:1236-1240.

40. Aller R, Moya JL, Moreira V, Boixeda D, Cano A, Picher J, GarcíaRull S, de Luis DA. Diagnosis of hepatopulmonary syndrome with contrast transesophageal echocardiography: advantages over contrast transthoracic echocardiography. Dig Dis Sci 1999;44:1243-1248.

41. Martinez G, Barberà JA, Navasa M, Roca J, Visa J, Rodriguez-Roisin R. Hepatopulmonary syndrome associated with cardiorespiratory disease. J Hepatol 1999;30:882-889.

42. Taillé C, Cadranel J, Bellocq A, Thabut G, Soubrane O, Durand F, Ichaï P, Duvoux C, Belghiti J, Calmus Y, et al. Liver transplantation for hepatopulmonary syndrome: a ten-year experience in Paris, France. Transplantation 2003;75:1482-1489.

43. Fallon MB, Krowka MJ, Brown RS, Trotter JF, Zacks S, Roberts KE, Shah VH, Kaplowitz N, Forman L, Wille K, et al. Impact of hepatopulmonary syndrome on quality of life and survival in liver transplant candidates. Gastroenterology 2008;135:1168-1175.

44. Krowka MJ, Tajik AJ, Dickson ER, Wiesner RH, Cortese DA. Intrapulmonary vascular dilatations (IPVD) in liver transplant candidates: screening by two-dimensional contrast-enhanced echocardiography. Chest 1990;97:1165-1170.

45. Schenk P, Fuhrmann V, Madl C, Funk G, Lehr S, Kandel O, Müller C. Hepatopulmonary syndrome: prevalence and predictive value of various cut offs for arterial oxygenation and their clinical consequences. Gut 2002;51:853-859.

46. Regev A, Yeshurun M, Rodriguez M, Sagie A, Neff GW, Molina EG, Schiff ER. Transient hepatopulmonary syndrome in a patient with acute hepatitis A. J Viral Hepat 2001;8:83-86.

47. Teuber G, Teupe C, Dietrich CF, Caspary WF, Buhl R, Zeuzem S Pulmonary dysfunction in non-cirrhotic patients with chronic viral hepatitis. Eur J Intern Med 2002;13:311-318.

48. Fuhrmann V, Madl C, Mueller C, Holzinger U, Kitzberger R, Funk GC, Schenk P. Hepatopulmonary syndrome in patients with hypoxic hepatitis. Gastroenterology 2006;131:69-75.

49. McFaul RC, Tajik AJ, Mair DD, Danielson GK, Seward JB. Development of pulmonary arteriovenous shunt after superior vena cavaright pulmonary artery (Glenn) anastomosis: report of four cases. Circulation 1977;55:212-216.

50. Law YM, Mack CL, Sokol RJ, Rice M, Parsley L, Ivy D. Cardiopulmonary manifestations of portovenous shunts from congenital absence of the portal vein: pulmonary hypertension and pulmonary vascular dilatation. Pediatr Transplant 2011;15:E162-E168.

51. Swanson KL, Wiesner RH, Krowka MJ. Natural history of hepatopulmonary syndrome: impact of liver transplantation. Hepatology 2005;41: 1122-1129.

52. Deberaldini M, Arcanjo AB, Melo E, da Silva RF, Felício HC, Arroyo PC Jr, Duca WJ, Cordeiro JA, da Silva RC. Hepatopulmonary syndrome: morbidity and survival after liver transplantation. Transplant Proc 2008;40:3512-3516.

53. Gupta S, Castel H, Rao RV, Picard M, Lilly L, Faughnan ME, PomierLayrargues G. Improved survival after liver transplantation in patients with hepatopulmonary syndrome. Am J Transplant 2010;10: 354-363.

54. Andrivet P, Cadranel J, Housset B, Herigault R, Harf A, Adnot S. Mechanisms of impaired arterial oxygenation in patients with liver cirrhosis and severe respiratory insufficiency: effects of indomethacin. Chest 1993;103:500-507.

55. Shijo H, Sasaki H, Nishimaru K, Okumura M. Recurrent intracranial hemorrhagic episodes in hepatopulmonary syndrome. Intern Med 1992;31:786-790.

56. Abrams GA, Rose K, Fallon MB, McGuire BM, Bloomer JR, van Leeuwen DJ, Tutton T, Sellers MT, Eckhoff DE, Bynon JS Jr. Hepatopulmonary syndrome and venous emboli causing intracerebral hemorrhages after liver transplantation: a case report. Transplantation 1999;68:1809-1811.

57. Schenk P, Schoniger-Hekele M, Fuhrmann V, Madl C, Silberhumer G, Muller C. Prognostic significance of the hepatopulmonary syndrome in patients with cirrhosis. Gastroenterology 2003;125:1042-1052.

58. Arguedas MR, Abrams GA, Krowka MJ, Fallon MB. Prospective evaluation of outcomes and predictors of mortality in patients with hepatopulmonary syndrome undergoing liver transplantation. Hepatology 2003;37:192-197.

59. Krowka MJ, Porayko MK, Plevak DJ, Pappas SC, Steers JL, Krom RAF, Wiesner RH. Hepatopulmonary syndrome with progressive hypoxemia as an indication for liver transplantation: case reports and literature review. Mayo Clin Proc 1997;72:44-53.

60. Krowka MJ, Mandell MS, Ramsay MA, Kawut SM, Fallon MB, Manzarbeitia C, Pardo M Jr, Marotta P, Uemoto S, Stoffel MP, et al. Hepatopulmonary syndrome and portopulmonary hypertension: a report of the multicenter liver transplant database. Liver Transpl 2004; 10:174-182.

61. Iyer VN, Swanson KL, Cartin-Ceba R, Dierkhising RA, Rosen CB, Heimbach JK, Wiesner RH, Krowka MJ. Hepatopulmonary syndrome: favorable outcomes in the MELD exception era. Hepatology (In press)

62. Advisory Committee on Immunization Practices. Recommended adult immunization schedule: United States, 2012. Ann Intern Med 2012; 156:211-217.

63. Sztrymf B, Rabiller A, Nunes H, Savale L, Lebrec D, Le Pape A, de Montpreville V, Mazmanian M, Humbert M, Hervé P. Prevention of hepatopulmonary syndrome and hyperdynamic state by pentoxifylline in cirrhotic rats. Eur Respir $J$ 2004;23:752-758.

64. Zhang J, Ling Y, Tang L, Luo B, Chacko BK, Patel RP, Fallon MB. Pentoxifylline attenuation of experimental hepatopulmonary syndrome. J Appl Physiol 2007;102:949-955.

65. Tanikella R, Philips GM, Faulk DK, Kawut SM, Fallon MB. Pilot study of pentoxifylline in hepatopulmonary syndrome. Liver Transpl 2008; 14:1199-1203.

66. Gupta LB, Kumar A, Jaiswal AK, Yusuf J, Mehta V, Tyagi S, Tempe DK, Sharma BC, Sarin SK. Pentoxifylline therapy for hepatopulmonary syndrome: a pilot study. Arch Intern Med 2008;168:1820-1823.

67. Poterucha JJ, Krowka MJ, Dickson ER, Cortese DA, Stanson AW, Krom RA. Failure of hepatopulmonary syndrome to resolve after liver transplantation and successful treatment with embolotherapy. Hepatology 1995;21:96-100.

68. Martínez-Palli G, Drake BB, Garcia-Pagan JC, Barberà JA, Arguedas MR, Rodriguez-Roisin R, Bosch J, Fallon MB. Effect of transjugular intrahepatic portosystemic shunt on pulmonary gas exchange in patients with portal hypertension and hepatopulmonary syndrome. World J Gastroenterol 2005;11:6858-6862.

69. Boyer TD, Haskal ZJ. The role of transjugular intrahepatic portosystemic shunt (TIPS) in the management of portal hypertension: update 2009. Hepatology 2010;51:306.

70. Collisson EA, Nourmand H, Fraiman MH, Cooper CB, Bellamy PE, Farmer DG, Vierling JM, Ghobrial RM, Busuttil RW. Retrospective analysis of the results of liver transplantation for adults with severe hepatopulmonary syndrome. Liver Transpl 2002;8:925-931.

71. Organ Procurement and Transplantation Network. Organ distribution: allocation of livers. 2012 [accessed 2012 August 5]. Available from: http://optn.transplant.hrsa.gov/policiesAndBylaws/policies.asp

72. Fallon MB, Mulligan DC, Gish RG, Krowka MJ. Model for end-stage liver disease (MELD) exception for hepatopulmonary syndrome. Liver Transpl 2006;12:S105-S107. 
73. Sulieman BM, Hunsicker LG, Katz DA, Voigt MD. OPTN policy regarding prioritization of patients with hepatopulmonary syndrome: does it provide equitable organ allocation? Am J Transplant 2008;8: 954-964.

74. Simonneau G, Robbins IM, Beghetti M, Channick RN, Delcroix M, Denton CP, Elliott CG, Gaine SP, Gladwin MT, Jing ZC, et al. Updated clinical classification of pulmonary hypertension. J Am Coll Cardiol 2009;54:S43-S54.

75. Edwards BS, Weir EK, Edwards WD, Ludwig J, Dykoski RK, Edwards JE. Coexistent pulmonary and portal hypertension: morphologic and clinical features. J Am Coll Cardiol 1987;10:1233-1238.

76. Tuder RM, Cool CD, Geraci MW, Wang J, Abman SH, Wright L, Badesch D, Voelkel NF. Prostacyclin synthase expression is decreased in lungs from patients with severe pulmonary hypertension. Am J Respir Crit Care Med 1999;159:1925-1932.

77. Neuhofer W, Gulberg V, Gerbes AL. Endothelin and endothelin receptor antagonism in portopulmonary hypertension. Eur J Clin Invest 2006;36:54-61.

78. Benjaminov FS, Prentice M, Sniderman KW, Siu S, Liu P, Wong F. Portopulmonary hypertension in decompensated cirrhosis with refractory ascites. Gut 2003;52:1355-1362.

79. Roberts KE, Fallon MB, Krowka MJ, Brown RS, Trotter JF, Peter I, Tighiouart H, Knowles JA, Rabinowitz D, Benza RL, et al. Genetic risk factors for portopulmonary hypertension in patients with advanced liver disease. Am J Respir Crit Care Med 2009;179: 835-842.

80. Black SM, Sanchez LS, Mata-Greenwood E, Bekker JM, Steinhorn RH, Fineman JR. sGC and PDE5 are elevated in lambs with increased pulmonary blood flow and pulmonary hypertension. Am J Physiol Lung Cell Mol Physiol 2001;281:L1051-L1057.

81. Murray F, MacLean MR, Pyne NJ. Increased expression of the cGMPinhibited cAMP-specific (PDE3) and cGMP binding cGMP-specific (PDE5) phosphodiesterases in models of pulmonary hypertension. Br J Pharmacol 2002;137:1187-1194.

82. Nagendran J, Archer SL, Soliman D, Gurtu V, Moudgil R, Haromy A, St Aubin C, Webster L, Rebeyka IM, Ross DB, et al. Phosphodiesterase type 5 is highly expressed in the hypertrophied human right ventricle, and acute inhibition of phosphodiesterase type 5 improves contractility. Circulation 2007;116:238-248.

83. Liu JQ, Zelko IN, Erbynn EM, Sham JS, Folz RJ. Hypoxic pulmonary hypertension: role of superoxide and NADPH oxidase (gp91phox). Am J Physiol Lung Cell Mol Physiol 2006;290:L2-L10.

84. Nisbet RE, Graves AS, Kleinhenz DJ, Rupnow HL, Reed AL, Fan TH, Mitchell PO, Sutliff RL, Hart CM. The role of NADPH oxidase in chronic intermittent hypoxia-induced pulmonary hypertension in mice. Am J Respir Cell Mol Biol 2009;40:601-609.

85. Austin ED, Cogan JD, West JD, Hedges LK, Hamid R, Dawson EP, Wheeler LA, Parl FF, Loyd JE, Phillips JA III. Alterations in oestrogen metabolism: implications for higher penetrance of familial pulmonary arterial hypertension in females. Eur Respir $J$ 2009;34: 1093-1099.

86. White K, Johansen AK, Nilsen M, Ciuclan L, Wallace E, Paton L, Campbell A, Morecroft I, Loughlin L, McClure JD, et al. Activity of the estrogen-metabolizing enzyme cytochrome P450 1B1 influences the development of pulmonary arterial hypertension. Circulation 2012; 126:1087-1098.

87. McLaughlin VV, Archer SL, Badesch DB, Barst RJ, Farber HW, Lindner JR, Mathier MA, McGoon MD, Park MH, Rosenson RS, et al. ACCF/AHA 2009 expert consensus document on pulmonary hypertension: a report of the American College of Cardiology Foundation Task Force on expert consensus documents and the American Heart Association developed in collaboration with the American College of Chest Physicians; American Thoracic Society, Inc.; and the Pulmonary Hypertension Association. J Am Coll Cardiol 2009;53:1573-1619.

88. Galiè N, Hoeper MM, Humbert M, Torbicki A, Vachiery JL, Barbera JA, Beghetti M, Corris P, Gaine S, Gibbs JS, et al. Guidelines for the diagnosis and treatment of pulmonary hypertension: Task Force for the Diagnosis and Treatment of Pulmonary Hypertension of the European Society of Cardiology (ESC), European Respiratory Society (ERS) and International Society of Heart and Lung Transplantation (ISHLT). Eur Respir J 2009;34:1219-1263.
89. Colle IO, Moreau R, Godinho E, Belghiti J, Ettori F, Cohen-Solal A, Mal H, Bernuau J, Marty J, Lebrec D, et al. Diagnosis of portopulmonary hypertension in candidates for liver transplantation: a prospective study. Hepatology 2003;37:401-409.

90. Murray KF, Carithers RL Jr. AASLD practice guidelines: evaluation of the patient for liver transplantation. Hepatology 2005;41: $1407-1432$

91. Lentine KL, Costa SP, Weir MR, Robb JF, Fleisher LA, Kasiske BL, Carithers RL, Ragosta M, Bolton K, Auerbach AD, et al. Cardiac disease evaluation and management among kidney and liver transplantation candidates: a scientific statement from the American Heart Association and the American College of Cardiology Foundation. Circulation 2012;126:617-663.

92. McDonnell PJ, Toye PA, Hutchins GM. Primary pulmonary hypertension and cirrhosis: are they related? Am Rev Respir Dis 1983;127: 437-441.

93. Krowka MJ, Swanson KL, Frantz RP, McGoon MD, Wiesner RH. Portopulmonary hypertension: results from a 10-year screening algorithm. Hepatology 2006;44:1502-1510.

94. Castro M, Krowka MJ, Schroeder DR, Beck KC, Plevak DJ, Rettke SR, Cortese DA, Wiesner RH. Frequency and clinical implications of increased pulmonary artery pressures in liver transplantation. Mayo Clin Proc 1996;71:543-551.

95. Torregrosa M, Genesca J, Gonzalez A, Evangelista A, Mora A, Margarit C, Esteban R, Guardia J. Role of Doppler echocardiography in the assessment of portopulmonary hypertension in liver transplantation candidates. Transplantation 2001;71:572-574.

96. Yang YY, Lin HC, Lee WC, Hou MC, Lee FY, Chang FY, Lee SD. Portopulmonary hypertension: distinctive hemodynamic and clinical manifestations. J Gastroenterol 2001;36:181-186.

97. Hadengue A, Benhayoun MK, Lebrec D, Benhamou JP. Pulmonary hypertension complicating portal hypertension: prevalence and relation to splanchnic hemodynamics. Gastroenterology 1991;100: $520-528$.

98. Fix OK, Bass NM, De Marco T, Merriman RB. Long-term follow-up of portopulmonary hypertension: effect of treatment with epoprostenol. Liver Transpl 2007;13:875-885.

99. Hoeper MM, Seyfarth HJ, Hoeffken G, Wirtz H, Spiekerkoetter E, Pletz MW, Welte T, Halank M. Experience with inhaled iloprost and bosentan in portopulmonary hypertension. Eur Respir J 2007;30: 1096-1102.

100. Kawut SM, Krowka MJ, Trotter JF, Roberts KE, Benza RL, Badesch DB, Taichman DB, Horn EM, Zacks S, Kaplowitz N, et al. Clinical risk factors for portopulmonary hypertension. Hepatology 2008;48: 196-203.

101. Talwalkar JA, Swanson KL, Krowka MJ, Andrews JC, Kamath PS. Prevalence of spontaneous portosystemic shunts in patients with portopulmonary hypertension and effect on treatment. Gastroenterology 2011;141:1673-1679.

102. Humbert M, Sitbon O, Chaouat A, Bertocchi M, Habib G, Gressin V, Yaici A, Weitzenblum E, Cordier JF, Chabot F, et al. Pulmonary arterial hypertension in France: results from a national registry. $A m$ J Respir Crit Care Med 2006;173:1023-1030.

103. Badesch DB, Raskob GE, Elliott CG, Krichman AM, Farber HW, Frost AE, Barst RJ, Benza RL, Liou TG, Turner M, et al. Pulmonary arterial hypertension: baseline characteristics from the REVEAL registry. Chest 2010;137:376-387.

104. Thenappan T, Shah SJ, Rich S, Gomberg-Maitland M. A USA-based registry for pulmonary arterial hypertension: 1982-2006. Eur Respir $J$ 2007;30:1103-1110.

105. Krowka MJ, Miller DP, Barst RJ, Taichman D, Dweik RA, Badesch DB, McGoon MD. Portopulmonary hypertension: a report from the US-based REVEAL registry. Chest 2012;141:906-915.

106. Robalino BD, Moodie DS. Association between primary pulmonary hypertension and portal hypertension: analysis of its pathophysiology and clinical, laboratory and hemodynamic manifestations. $J$ Am Coll Cardiol 1991;17:492-498.

107. Kuo PC, Plotkin JS, Johnson LB, Howell CD, Laurin JM, Bartlett ST, Rubin LJ. Distinctive clinical features of portopulmonary hypertension. Chest 1997;112:980-986.

108. Swanson KL, Krowka MJ. Arterial oxygenation associated with portopulmonary hypertension. Chest 2002;121:1869-1875. 
109. Rich S, Dantzker DR, Ayres SM, Bergofsky EH, Brundage BH, Detre KM, Fishman AP, Goldring RM, Groves BM, Koerner SK, et al. Primary pulmonary hypertension: a national prospective study. Ann Intern Med 1987;107:216-223.

110. Gazetopoulos N, Salonikides N, Davies H. Cardiopulmonary function in patients with pulmonary hypertension. Br Heart J 1974;36:19-28.

111. Dantzker DR, Bower JS. Mechanisms of gas exchange abnormality in patients with chronic obliterative pulmonary vascular disease. J Clin Invest 1979;64:1050-1055.

112. Dantzker DR, D'Alonzo GE. Pulmonary gas exchange and exercise performance in pulmonary hypertension. Chest 1985;88:255S-257S

113. Raffy O, Sleiman C, Vachiery F, Mal H, Roue C, Hadengue A, Jebrak G, Fournier M, Pariente R. Refractory hypoxemia during liver cirrhosis: hepatopulmonary syndrome or "primary" pulmonary hypertension? Am J Respir Crit Care Med 1996;153:1169-1171.

114. Swanson KL, Wiesner RH, Nyberg SL, Rosen CB, Krowka MJ. Survival in portopulmonary hypertension: Mayo clinic experience categorized by treatment subgroups. Am J Transplant 2008;8: 2445-2453.

115. Kawut SM, Taichman DB, Ahya VN, Kaplan S, Archer-Chicko CL, Kimmel SE, Palevsky HI. Hemodynamics and survival of patients with portopulmonary hypertension. Liver Transpl 2005;11:1107-1111.

116. Le Pavec J, Souza R, Hervé P, Lebrec D, Savale L, Tcherakian C, Jaïs $\mathrm{X}$, Yaici A, Humbert M, Simonneau G, et al. Portopulmonary hypertension: survival and prognostic factors. Am J Respir Crit Care Med 2008;178:637-643.

117. Krowka MJ, Plevak DJ, Findlay JY, Rosen CB, Wiesner RH, Krom RA. Pulmonary hemodynamics and perioperative cardiopulmonaryrelated mortality in patients with portopulmonary hypertension undergoing liver transplantation. Liver Transpl 2000;6:443-450.

118. Taura P, Garcia-Valdecasas JC, Beltran J, Izquierdo E, Navasa M, Sala-Blanch J, Mas A, Balust J, Grande L, Visa J. Moderate primary pulmonary hypertension in patients undergoing liver transplantation. Anesth Analg 1996;83:675-680.

119. Sussman N, Kaza V, Barshes N, Stribling R, Goss J, O'Mahony C, Zhang E, Vierling J, Frost A. Successful liver transplantation following medical management of portopulmonary hypertension: a single-center series. Am J Transplant 2006;6:2177-2182.

120. Ashfaq M, Chinnakotla S, Rogers L, Ausloos K, Saadeh S, Klintmalm GB, Ramsay M, Davis GL. The impact of treatment of portopulmonary hypertension on survival following liver transplantation. Am J Transplant 2007;7:1258-1264.

121. Kett DH, Acosta RC, Campos MA, Rodriguez MJ, Quartin AA, Schein RM. Recurrent portopulmonary hypertension after liver transplantation: management with epoprostenol and resolution after retransplantation. Liver Transpl 2001;7:645-648.

122. Aucejo F, Miller C, Vogt D, Eghtesad B, Nakagawa S, Stoller JK Pulmonary hypertension after liver transplantation in patients with antecedent hepatopulmonary syndrome: a report of 2 cases and review of the literature. Liver Transpl 2006;12:1278-1282.

123. Krowka MJ, Fallon MB, Mulligan DC, Gish RG. Model for end-stage liver disease (MELD) exception for portopulmonary hypertension. Liver Transpl 2006;12:S114-S116.

124. Colombato LA, Spahr L, Martinet JP, Dufresne MP, Lafortune M Fenyves D, Pomier-Layrargues G. Haemodynamic adaptation two months after transjugular intrahepatic portosystemic shunt (TIPS) in cirrhotic patients. Gut 1996;39:600-604.

125. Stanley AJ, Redhead DN, Bouchier IA, Hayes PC. Acute effects of transjugular intrahepatic portosystemic stent-shunt (TIPSS) procedure on renal blood flow and cardiopulmonary hemodynamics in cirrhosis. Am J Gastroenterol 1998;93:2463-2468.

126. Fuster V, Steele PM, Edwards WD, Gersh BJ, McGoon MD, Frye RL. Primary pulmonary hypertension: natural history and the importance of thrombosis. Circulation 1984;70:580-587.

127. Rich S, Kaufmann E, Levy PS. The effect of high doses of calciumchannel blockers on survival in primary pulmonary hypertension. $N$ Engl J Med 1992;327:76-81.

128. Frank H, Mlczoch J, Huber K, Schuster E, Gurtner HP, Kneussl M The effect of anticoagulant therapy in primary and anorectic druginduced pulmonary hypertension. Chest 1997;112:714-721.

129. Kawut SM, Horn EM, Berekashvili KK, Garofano RP, Goldsmith RL Widlitz AC, Rosenzweig EB, Kerstein D, Barst RJ. New predictors of outcome in idiopathic pulmonary arterial hypertension. Am J Cardiol 2005;95:199-203.

130. Sitbon O, Humbert M, Jaïs X, Ioos V, Hamid AM, Provencher S, Garcia G, Parent F, Hervé P, Simonneau G. Long-term response to calcium channel blockers in idiopathic pulmonary arterial hypertension. Circulation 2005;111:3105-3111.

131. Montani D, Savale L, Natali D, Jaïs X, Hervé P, Garcia G, Humbert M, Simonneau G, Sitbon O. Long-term response to calcium-channel blockers in non-idiopathic pulmonary arterial hypertension. Eur Heart J 2010;31:1898-1907.

132. Badesch DB, Abman SH, Ahearn GS, Barst RJ, McCrory DC, Simonneau G, McLaughlin VV. Medical therapy for pulmonary arterial hypertension: ACCP evidence-based clinical practice guidelines. Chest 2004;126:35S-62S.

133. Provencher S, Hervé P, Jaïs X, Lebrec D, Humbert M, Simonneau G, Sitbon O. Deleterious effects of beta-blockers on exercise capacity and hemodynamics in patients with portopulmonary hypertension. Gastroenterology 2006;130:120-126.

134. Kuo PC, Johnson LB, Plotkin JS, Howell CD, Bartlett ST, Rubin LJ. Continuous intravenous infusion of epoprostenol for the treatment of portopulmonary hypertension. Transplantation 1997;63: 604-606

135. Plotkin JS, Kuo PC, Rubin LJ, Gaine S, Howell CD, Laurin J, Njoku MJ, Lim JW, Johnson LB. Successful use of chronic epoprostenol as a bridge to liver transplantation in severe portopulmonary hypertension. Transplantation 1998;65:457-459.

136. Krowka MJ, Frantz RP, McGoon MD, Severson C, Plevak DJ Wiesner RH. Improvement in pulmonary hemodynamics during intravenous epoprostenol (prostacyclin): a study of 15 patients with moderate to severe portopulmonary hypertension. Hepatology 1999;30:641-648.

137. Findlay JY, Plevak DJ, Krowka MJ, Sack EM, Porayko MK. Progressive splenomegaly after epoprostenol therapy in portopulmonary hypertension. Liver Transpl Surg 1999;5:362-365.

138. Touma W, Nayak RP, Hussain Z, Bacon BR, Kudva GC. Epoprostenolinduced hypersplenism in portopulmonary hypertension. Am J Med Sci 2012;344:345-349.

139. Sakai T, Planinsic RM, Mathier MA, de Vera ME, Venkataramanan R. Initial experience using continuous intravenous treprostinil to manage pulmonary arterial hypertension in patients with end-stage liver disease. Transpl Int 2009;22:554-561.

140. Melgosa MT, Ricci GL, García-Pagan JC, Blanco I, Escribano P, Abraldes JG, Roca J, Bosch J, Barberà JA. Acute and long-term effects of inhaled iloprost in portopulmonary hypertension. Liver Transpl 2010;16: 348-356.

141. Galiè N, Ghofrani HA, Torbicki A, Barst RJ, Rubin LJ, Badesch D, Fleming T, Parpia T, Burgess G, Branzi A, et al. Sildenafil citrate therapy for pulmonary arterial hypertension. N Engl J Med 2005;353: 2148-2157.

142. Reichenberger F, Voswinckel R, Steveling E, Enke B, Kreckel A, Olschewski H, Grimminger F, Seeger W, Ghofrani HA. Sildenafil treatment for portopulmonary hypertension. Eur Respir J 2006;28: $563-567$.

143. Gough MS, White RJ. Sildenafil therapy is associated with improved hemodynamics in liver transplantation candidates with pulmonary arterial hypertension. Liver Transpl 2009;15:30-36.

144. Hemnes AR, Robbins IM. Sildenafil monotherapy in portopulmonary hypertension can facilitate liver transplantation. Liver Transpl 2009; 15:15-19

145. Rubin LJ, Badesch DB, Barst RJ, Galiè N, Black CM, Keogh A, Pulido T, Frost A, Roux S, Leconte I, et al. Bosentan therapy for pulmonary arterial hypertension. N Engl J Med 2002;346:896-903.

146. Halank M, Miehlke S, Hoeffken G, Schmeisser A, Schulze M, Strasser $\mathrm{RH}$. Use of oral endothelin-receptor antagonist bosentan in the treatment of portopulmonary hypertension. Transplantation 2004;77: 1775-1776

147. Hinterhuber L, Graziadei IW, Kahler CM, Jaschke W, Vogel W. Endothelin-receptor antagonist treatment of portopulmonary hypertension. Clin Gastroenterol Hepatol 2004;2:1039-1042.

148. Hoeper MM, Halank M, Marx C, Hoeffken G, Seyfarth HJ, Schauer J, Niedermeyer J, Winkler J. Bosentan therapy for portopulmonary hypertension. Eur Respir J 2005;25:502-508. 
149. Kuntzen C, Gulberg V, Gerbes AL. Use of a mixed endothelin receptor antagonist in portopulmonary hypertension: a safe and effective therapy? Gastroenterology 2005;128:164-168.

150. Grander W, Eller P, Fuschelberger R, Tilg H. Bosentan treatment of portopulmonary hypertension related to liver cirrhosis owing to hepatitis C. Eur J Clin Invest 2006;36:67-70.

151. Barth F, Gerber PJ, Reichen J, Dufour JF, Nicod LP. Efficiency and safety of bosentan in Child C cirrhosis with portopulmonary hypertension and renal insufficiency. Eur J Gastroenterol Hepatol 2006;18: 1117-1119.

152. Savale L, Magnier R, Le Pavec J, Jaïs X, Montani D, O’Callaghan DS, Humbert M, Dingemanse J, Simonneau G, Sitbon O. Efficacy, safety, and pharmacokinetics of bosentan in portopulmonary hypertension. Eur Respir J (In press)

153. Galiè N, Olschewski H, Oudiz RJ, Torres F, Frost A, Ghofrani HA, Badesch DB, McGoon MD, McLaughlin VV, Roecker EB, et al. Ambrisentan for the treatment of pulmonary arterial hypertension: results of the ambrisentan in pulmonary arterial hypertension, randomized, double-blind, placebo-controlled, multicenter, efficacy (ARIES) study 1 and 2. Circulation 2008;117:3010 3019

154. Cartin-Ceba R, Swanson K, Iyer V, Wiesner RH, Krowka MJ. Safety and efficacy of ambrisentan for the treatment of portopulmonary hypertension. Chest 2011;139:109-114. 